\title{
Mikrostruktura i właściwości mechaniczne wielościegowych złączy teowych stali konstrukcyjnej S355 spawanych na zrobotyzowanym stanowisku metodą MAG
}

\author{
Microstructure and mechanical properties \\ of S355 structural steel multirun tee-joint \\ made by robot motioned MAG method
}

\section{Streszczenie}

W artykule przedstawiono propozycję konstrukcji wielościegowego złącza teowego ze spoiną czołową stali konstrukcyjnej S355J2G3, wykonanego na zrobotyzowanym stanowisku spawalniczym. Program badań obejmował dobór parametrów procesu w celu wyznaczenia ilości ciepła potrzebnej do uzyskania złącza wysokiej jakości, tzn. bez niezgodności spawalniczych. W celu określenia jakości złącza przeprowadzono jego ocenę wizualną oraz badania makro- i mikrostruktury. Właściwości mechaniczne uzyskanego złącza określono przez pomiary twardości metodą Vickersa przy obciążeniu $98,1 \mathrm{~N}$

\section{Abstract}

The paper proposes of S355J2G3 steel multirun tee joint with butt-weld structure for robot motion automatic welding process. The research program included the process parameters selection to determine the high quality joint without any imperfections. The satisfied heat input for each bead of weld is calculated. Moreover, in order to determine the quality of joint macro- and microstructure were carried out. The appearance of weld is evaluated with the use of visual testing. The mechanical properties in specified zones of weld were carried out by hardness measurement with the use of Vickers method with the load of $98,1 \mathrm{~N}$.

\section{Wstęp}

Dynamiczny rozwój i rozszerzające się obszary możliwości zastosowań systemów robotyzacji procesów spawania skłaniają do prowadzenia badań nad konstrukcją złączy o różnym kształcie przeznaczonych dla przemysłu samochodowego, stoczniowego, kolejowego i energetycznego. Te obszary gospodarki są szczególnie istotne w krajach uprzemysłowionych,

Mgr inż. Krzysztof Pańcikiewicz, dr inż. Lechosław Tuz - AGH Akademia Górniczo-Hutnicza w Krakowie.

w których prowadzone są prace nad nowymi rozwiązaniami i konstrukcjami, jak również opracowywane są projekty modernizacji konstrukcji już istniejących w oparciu o rozwiązania modułowe. Przy ich wytwarzaniu wykorzystywane są coraz częściej roboty. Świadczyć o tym może m.in. liczba wdrażanych w Polsce aplikacji [1]. Siennicki [2] wskazuje na kluczową rolę robotów jako sprzyjających rozwojowi i postępowi technicznemu. Sformułował on, już w latach 80. XX w., wnioski umożliwiające zastosowanie robotów w przemyśle budowy taboru kolejowego, wskazane poniżej. Są one aktualne do dnia dzisiejszego [2, 3].

1. Profile hutnicze $i$ detale wycinane tlenowo z blach nie zapewniają powtarzalności umiejscowienia złącza spawanego w przestrzeni pracy robota. 
Obecnie uzyskanie niezbędnych tolerancji możliwe jest przy zastosowaniu cięcia łukiem plazmowym lub wiązką laserową. Innym, również korzystnym, rozwiązaniem jest stosowanie robotów adaptacyjnych wykonujących pomiar rzeczywistego położenia złącza przed spawaniem, a podczas procesu śledzących ułożenie spoiny przez różnego rodzaju sensory [4].

2. Sterowanie ruchami robota i parametrami spawania powinno umożliwiać:

- zmianę parametrów na długości spoiny oraz wypełnienia krateru,

- wykonywanie spoin wielowarstwowych,

- wykonywanie spoin ruchem zakosowym,

- optymalizowanie parametrów w czasie spawania.

3. Robot powinien realizować zaprogramowane zadania produkcyjne bez udziału operatora, który w tym czasie wykonuje inne prace, np. montaż, sczepianie, załadunek części. Wymaga to przygotowania odpowiednich przyrządów do montażu i spawania podzespołów na robocie oraz zastosowania urządzeń peryferyjnych sterowanych przez niego, służących do pozycjonowania spawanego wyrobu.

4. Robotyzacja procesu spawania wymaga znajomości zalet i ograniczeń dla poszczególnych konstrukcji oraz niezbędnego przeszkolenia personelu.

Niezbędne warunki jakie musi spełniać robot przemysłowy do prac spawalniczych są następujące [5]:

- sześcioosiowa mechanika,

- dostosowanie do spawania łukiem w osłonie gazów,

- proces spawania prowadzony z ustalonymi empirycznie parametrami,

- wyszukiwanie i podążanie elektrody za złączem,

- robot adaptacyjny, zdolny do korekcji trajektorii podczas procesu spawania,

- sensory wyszukiwania i śledzenia spoiny nie mogą utrudniać dostępu do złącza spawanego.
Kierunki rozwoju robotyzacji i automatyzacji procesów spawalniczych wymuszają konieczność opracowywania konstrukcji złączy spawanych oraz opracowywania technologii ich wykonywania w różnych pozycjach.

W tym celu zaprojektowano złącze teowe ze spoiną czołową, które następnie wykonano na zrobotyzowanym stanowisku wyposażonym w 6-osiowego robota. W oparciu o wykonaną próbę spawania i zastosowane parametry procesu określono niezbędną ilość ciepła wprowadzaną do złącza. Ocenę jakości złącza przeprowadzono w oparciu o ocenę wizualną, badania metalograficzne makroskopowe i mikrostruktury złącza oraz pomiary twardości.

Do wykonania złączy zastosowano stal konstrukcyjną o podwyższonej granicy plastyczności w stanie normalizowanym, znajdującą zastosowanie w konstrukcjach samochodów ciężarowych, taboru kolejowego i przemyśle stoczniowym.

\section{Materiał do badań}

Do badań użyto blachy o grubości $18 \mathrm{~mm}$ ze stali S355J2G3 wg EN 10025-2 o składzie chemicznym zamieszczonym w tablicy I i właściwościach mechanicznych w tablicy II. Do spawania zastosowano drut lity G 464 M G3Si wg PN-EN ISO 14341-A o składzie chemicznym podanym w tablicy III i średnicy 1,2 mm.

Złącze teowe przygotowano zgodnie z PN-EN ISO 9692-1 (poz. 2.9.1) wykonując symetryczne fazowanie pod kątem $55^{\circ}$ blachy pionowej. Sposób przygotowania blach wraz z wymiarami geometrycznymi przedstawiono na rysunku 1. Powierzchnię blach przed spawaniem w obszarze do $40 \mathrm{~mm}$ od osi spoiny oczyszczono do połysku metalicznego, a następnie odtłuszczono $\mathrm{Na}$ podstawie zastosowanych parametrów procesu

Tablica I. Skład chemiczny stali S355J2G3 wg EN 10025-2

Table I. Chemical composition of S355J2G3 steel acc. to EN 10025-2

\begin{tabular}{|c|c|c|c|c|c|c|c|}
\hline \multicolumn{2}{|c|}{ Stal } & \multicolumn{4}{c|}{ Zawartość pierwiastków, \% mas. max } \\
\hline Nazwa wg. PN-EN 10027-1 & Numer wg PN-EN 10027-2 & C dla 16 $\div 40 \mathrm{~mm}$ & $\mathrm{Mn}$ & $\mathrm{Si}$ & $\mathrm{P}$ & $\mathrm{S}$ & $\mathrm{N}$ \\
\hline S355J2G3 & 1.0577 & 0,20 & 1,6 & 0,55 & 0,025 & 0,025 & - \\
\hline
\end{tabular}

Tablica II. Właściwości mechaniczne stali S355J2G3 wg EN 10025-2

Table II. Mechanical properties of S355J2G3 steel acc. to EN 10025-2

\begin{tabular}{|c|c|c|c|}
\hline $\begin{array}{c}\text { Granica plastyczności } \\
\mathrm{R}_{\mathrm{e} \text { min }}, \mathrm{MPa}\end{array}$ & $\begin{array}{c}\text { Wytrzymałość na rozciąganie } \\
\mathrm{R}_{\mathrm{m}}, \mathrm{MPa}\end{array}$ & $\begin{array}{c}\text { Wydłużenie przy zerwaniu } \\
\mathrm{A}_{5}, \% \text { min. }\end{array}$ & $\begin{array}{c}\text { Minimalna praca łamania } \\
\mathrm{w}-20^{\circ} \mathrm{C}, \mathrm{J}\end{array}$ \\
\hline 355 & $470 \div 630$ & 22 & 27 \\
\hline
\end{tabular}

Tablica III. Skład chemiczny drutu elektrodowego zastosowanego do wykonania złącza Table III. Chemical composition of electrode wire used in the process

\begin{tabular}{|c|c|c|c|}
\hline \multirow{2}{*}{ Oznaczenie drutu } & \multicolumn{3}{|c|}{ Zawartość pierwiastków, \% mas. } \\
\cline { 2 - 4 } & $\mathrm{C}$ & Mn & Si \\
\hline ISO 14341-A: G 46 4 M G3Si & $0,06 \div 0,14$ & $1,3 \div 1,6$ & $0,7 \div 1,0$ \\
\hline
\end{tabular}


z zależności (1) wyznaczono ilość ciepła wprowadzaną podczas wykonywania każdego ściegu.

$$
E=\frac{60 \cdot I \cdot U}{v} \eta \quad\left[\frac{\mathrm{kJ}}{\mathrm{mm}}\right]
$$

gdzie: I - natężenie prądu spawania w A, U - napięcie łuku w $V, v$ - prędkość spawania $\mathrm{w} \mathrm{mm} / \mathrm{min}, \eta$ - sprawność cieplna metody - przyjęto wartość 0,8 .

Ustalono kolejność i pozycje spawania dla poszczególnych ściegów (rys. 2). Pozycje spawania oraz wartości wyznaczonej ilości wprowadzanego ciepła zamieszczono w tablicy IV. Proces spawania prowadzono odpowiednio prądem stałym z biegunowością dodatnią na elektrodzie - ścieg 1 i 2, oraz z prądem stałym pulsującym - ścieg 3 i 4 (wg rys. 2).

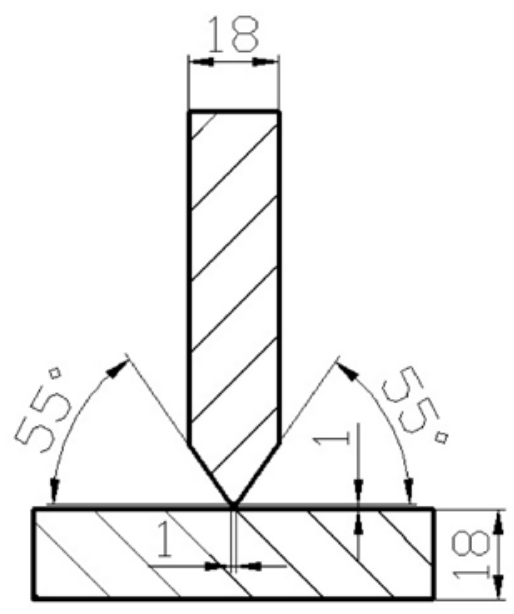

Rys. 1. Konstrukcja złącza teowego ze spoiną czołową Fig. 1. Tee joint with butt-weld structure

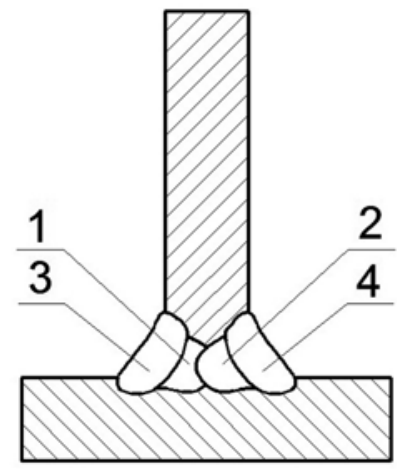

Rys. 2. Kolejność spawania

Fig. 2. Welding sequence

Tablica IV. Pozycje wykonywania poszczególnych ściegów i wartości energii liniowej

Table IV. Welding positions for each bead and the heat input

\begin{tabular}{|c|c|c|c|}
\hline $\begin{array}{c}\text { Numer ściegu } \\
\text { wg rys. 2 }\end{array}$ & $\begin{array}{c}\text { Rodzaj } \\
\text { prądu }\end{array}$ & $\begin{array}{c}\text { Pozycja } \\
\text { spawania }\end{array}$ & $\begin{array}{c}\text { Ilość wprowadzanego } \\
\text { ciepła, } \mathrm{kJ} / \mathrm{mm}\end{array}$ \\
\hline 1 & DC $(+)$ & PC & 0,85 \\
\hline 2 & DC $(+)$ & PA & 0,60 \\
\hline 3 & DC $(+)$ puls & PA & 2,15 \\
\hline 4 & DC $(+)$ puls & PB & 1,15 \\
\hline
\end{tabular}

\section{Program badań}

Proces spawania przeprowadzono na zrobotyzowanym stanowisku spawalniczym wyposażonym w robota 6-osiowego sprzężonego ze źródłem spawalniczym MAG/MAG Puls. Jako gaz osłonowy zastosowano mieszaninę M21 wg PN-EN ISO $14175\left(\mathrm{Ar}+15 \div 25 \% \mathrm{CO}_{2}\right)$.

Program badań obejmował przeprowadzenie oceny wizualnej złączy, badania metalograficzne makroskopowe i mikrostruktury przy wykorzystaniu mikroskopu świetlnego Leica umożliwiającego cyfrowe zapisywanie obrazu oraz ocenę właściwości mechanicznych złączy przez pomiary twardości w charakterystycznych obszarach złącza. Do pomiaru twardości metodą Vickersa przy obciążeniu 98,1 N zastosowano twardościomierz Zwick Roell. Czas pomiaru $10 \mathrm{~s}$.

W celu ujawnienia makro- i mikrostruktury zgłady trawiono $4 \%$ nitalem. Czas trawienia wynosił $5 \mathrm{~s}$.

\section{Wyniki badań}

\section{Makrostruktura}

Na rysunku 3 przedstawiono makrostrukturę złącza, w którym zaobserwowano pęknięcie w ściegu 1 (energia linowa $0,95 \mathrm{~kJ} / \mathrm{mm}$ ). Zmniejszenie energii liniowej do wartości $0,85 \mathrm{~kJ} / \mathrm{mm}$ umożliwiło jego uniknięcie. Linia wtopienia pomiędzy poszczególnymi ściegami (w szczególności pomiędzy 1 i 3 ) jest wyraźnie zarysowana. Wzdłuż niej znajduje się strefa wpływu ciepła o szerokości dochodzącej do $3 \mathrm{~mm}$. Kształt poszczególnych ściegów wskazuje na poprawnie dobrane parametry procesu spawania (ilości wprowadzanego ciepła). Przy wartościach energii wskazanych w tablicy IV nie zaobserwowano występowania niezgodności spawalniczych.

Pomiar odkształcenia kątowego złącza, obejmujący wykonanie pomiaru wartości kątów po ustawieniu i sczepieniu blach przed spawaniem oraz po spawaniu wskazuje na zmianę o $2^{\circ} \mathrm{w}$ kierunku ściegów 1 i 3.

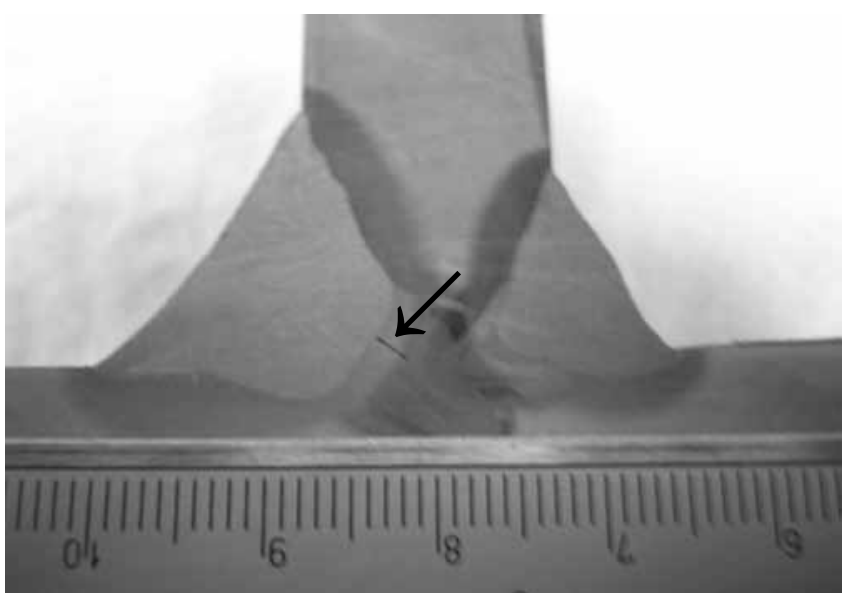

Rys. 3. Makrostruktura złącza teowego ze spoiną czołową Fig. 3. Macrostructure of tee-joint with the butt-weld 


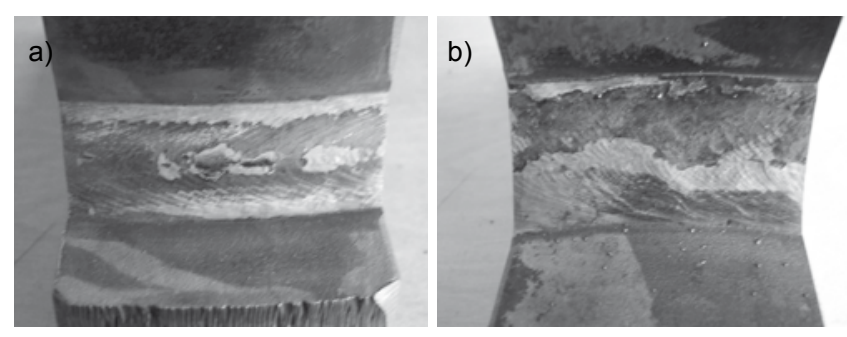

Rys. 4. Lico spoiny: a) ścieg 3, b) ścieg 4

Fig. 4. Face of the weld: a) bead no. 3, b) bead no. 4

Lico spoin jest równe i płaskie $z$ widocznymi łuskami na powierzchni ułożonymi regularnie (rys. 4).

\section{Mikrostruktura}

Ocenę mikrostruktury przeprowadzono dla materiału rodzimego, strefy wpływu ciepła i spoiny. W materiale rodzimym występuje pasmowa struktura ferrytycznoperlityczna, charakterystyczna dla stali konstrukcyjnej w stanie normalizowanym. Ułożenie poszczególnych ziarn ma charakter pasmowy. Pasmowość struktury jest skutkiem krystalizacji z lokalnym nadmiarem lub niedomiarem składników stopowych. Obszary o małej zawartości manganu przemieniają się $\mathrm{w}$ ferryt wcześniej. Ze względu na ograniczoną rozpuszczalność węgla w ferrycie (do 0,0218\%) nadmiar tego pierwiastka wypychany jest do austenitu, do momentu przemiany $w$ perlit (temp. $A_{1}$ ). Mikrostruktura blachy przedstawiona jest na rysunkach $5 \div 7$.

W strefie wpływu ciepła SWC obserwowano struktury charakterystyczne dla złącza spawanego stali konstrukcyjnych. Zidentyfikowano, obserwując od strony materiału rodzimego, obszar częściowego przekrystalizowania, normalizowania, przegrzania oraz częściowego stopienia, których struktury przedstawiono na rysunkach $8 \div 11$.

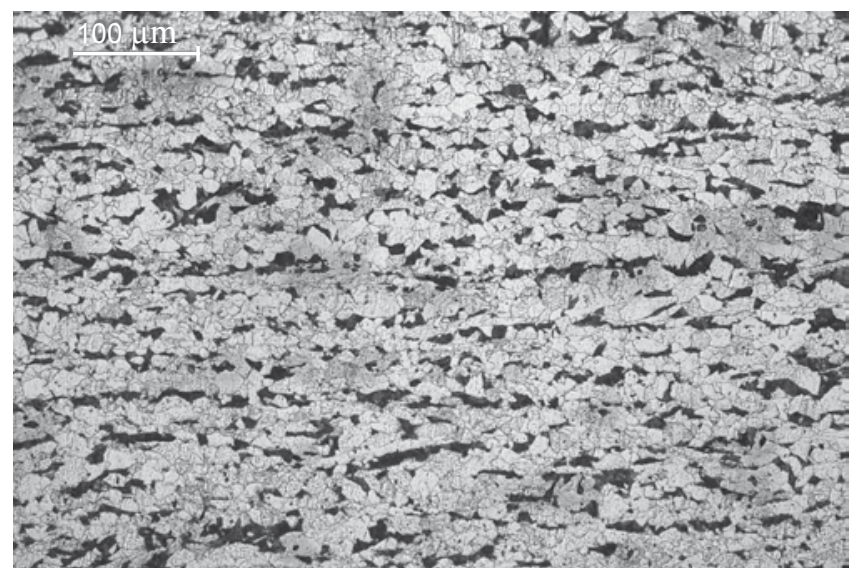

Rys. 5. Pasmowa ferrytyczno-perlityczna mikrostruktura materiału rodzimego blachy poziomej. Mikroskopia świetlna. Trawienie: Nital $4 \%$ Fig. 5. Ferritic-pearlitic banded microstructure of base metal in the horizontal plate of joint. Light microscopy. Etching: $4 \%$ Nital

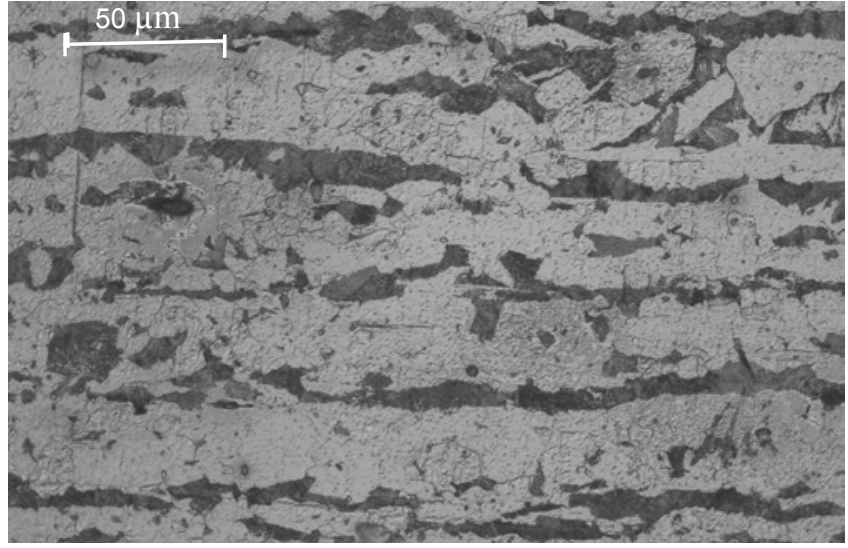

Rys. 6. Pasmowa ferrytyczno-perlityczna mikrostruktura materiału rodzimego blachy pionowej z rys. 5 . Mikroskopia świetlna. Trawienie: Nital $4 \%$

Fig. 6. Ferritic-pearlitic banded microstructure of base metal in the vertical plate of joint from fig. 5 . Light microscopy. Etching: $4 \%$ Nital

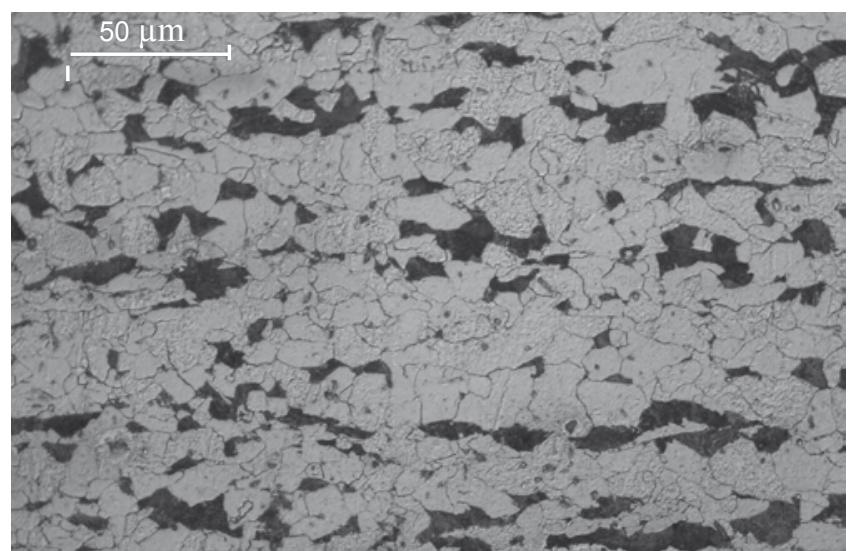

Rys. 7. Pasmowa ferrytyczno-perlityczna mikrostruktura materiału rodzimego blachy poziomej z rys. 5 . Mikroskopia świetlna. Trawienie: Nital $4 \%$

Fig. 7. Ferritic-pearlitic banded microstructure of base metal in the horizontal plate of joint from fig. 5 . Light microscopy. Etching: $4 \%$ Nital

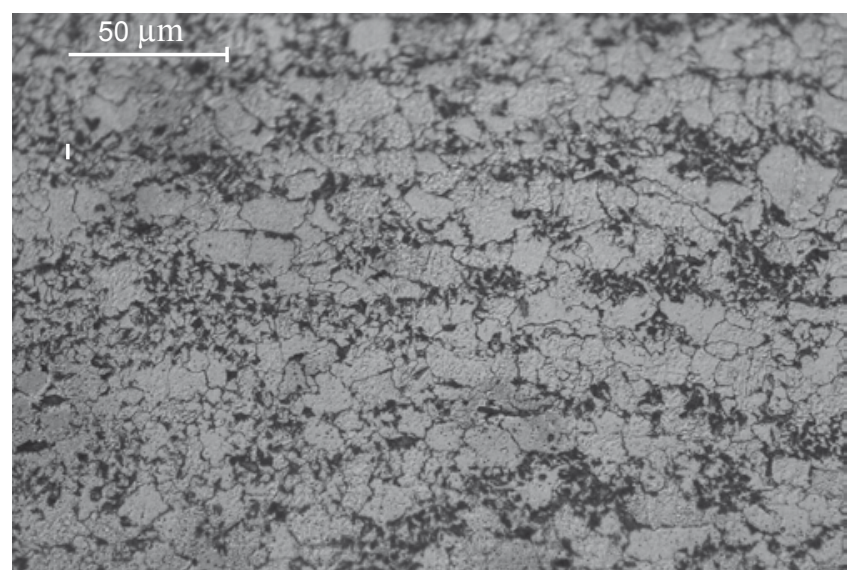

Rys. 8. Mikrostruktura w strefie wpływu ciepła w obszarze częściowego przekrystaliozwania (pomiędzy temperaturą $\mathrm{A}_{1}$ i $\mathrm{A}_{3}$ ). Pasmowa mikrostruktura ferrytyczno-perlityczna. W obszarze nagrzanym do zakresu dwufazowego $\alpha+\gamma$, następuje przemiana perlitu w austenit. Podczas chłodzenia austenit przemienia się $w$ ferryt i perlit. Mikroskopia świetlna. Trawienie: Nital $4 \%$

Fig. 8. The microstructure of the heat affected zone in the area of partial recrystallization (temperature between $A_{1}$ and $A_{3}$ ). Ferritic-pearlitic banded microstructure. In dual-phase $\alpha+y$ temperature range pearlite transforms into austenite. In cooling austenite transforms into ferrite and pearlite. Light microscopy. Etching: Nital 4\% 


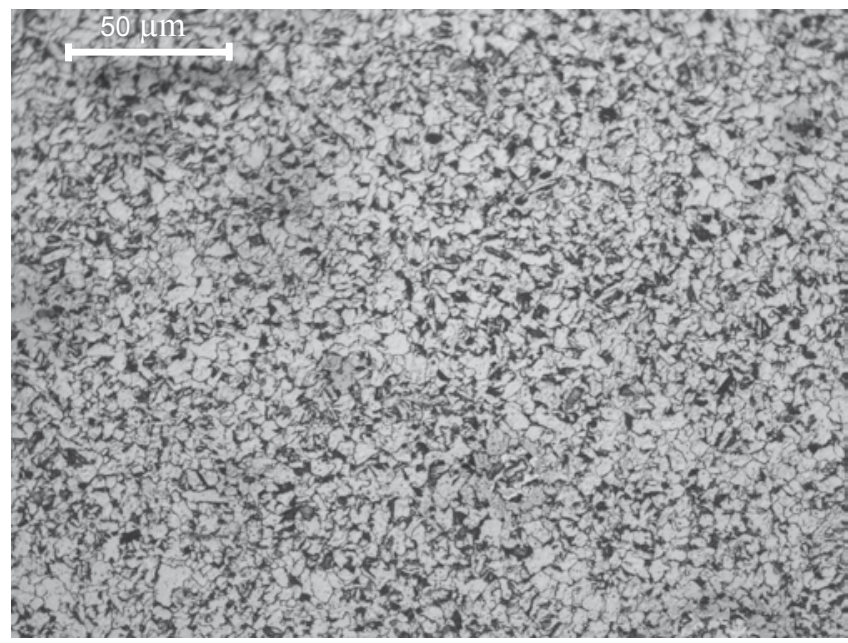

Rys. 9. Mikrostruktura w strefie wpływu ciepła w obszarze normalizowania (powyżej temperatury $\mathrm{A}_{3}$ ). Widoczna struktura ferrytyczno-perlityczna z równomiernie rozłożonymi ziarnami. Brak pasmowości struktury. Obserwowane rozdrobnienie ziarn w porównaniu z materiałem rodzimym. Mikroskopia świetlna. Trawienie: Nital $4 \%$

Fig. 9. The microstructure of the heat affected zone in the normalization area (temperature above $A_{3}$ ). Ferritic-pearlitic microstructure with homogeneity distributed grains. Without banded structure. Refinement of structure in comparison to base metal. Light microscopy. Etching: Nital $4 \%$

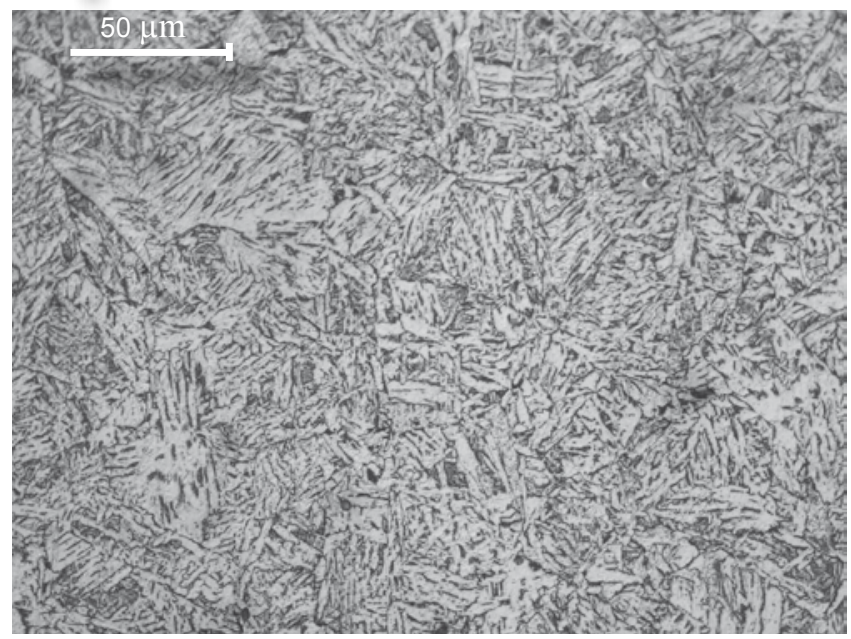

Rys. 10. Mikrostruktura w strefie wpływu ciepła w obszarze przegrzania. Gruboziarnista struktura byłego austenitu z zarysowanymi granicami ziarn i wewnątrz struktura ferrytu płytkowego - struktura Widmanstättena. Mikroskopia świetlna. Trawienie: Nital 4\%

Fig. 10. The microstructure of the heat affected zone in the overheating area. Primary coarse-grained microstructure of prior austenite with grain boundaries outlined and inside ferrite plates - Widmanstätten structure. Light microscopy. Etching: Nital 4\%

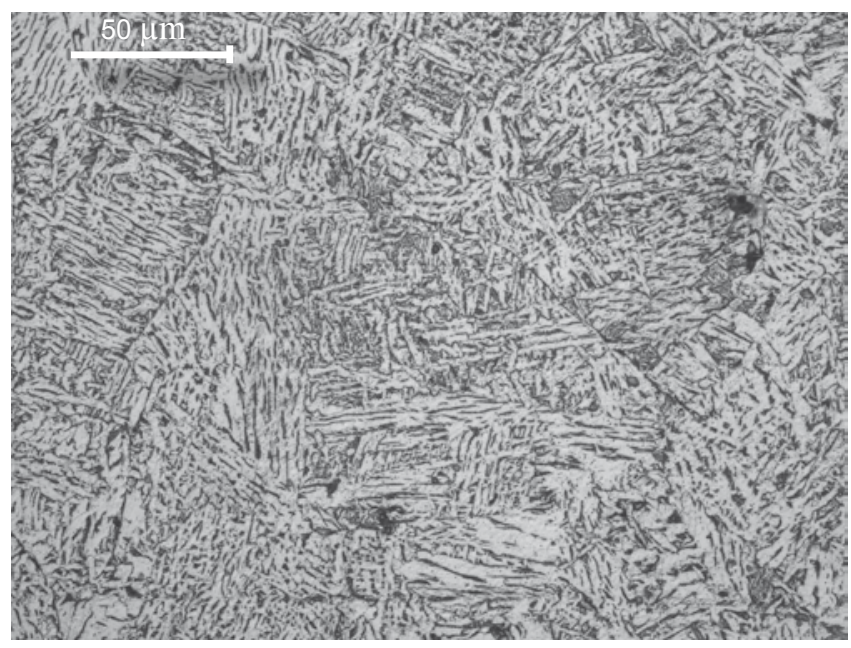

Rys. 11. Mikrostruktura w strefie wpływu ciepła w obszarze przegrzania. Gruboziarnista struktura byłego austenitu z zarysowanymi granicami ziarn i wewnatrz struktura ferrytu płytkowego - struktura Widmanstättena. Mikroskopia świetlna. Trawienie: Nital $4 \%$

Fig. 11. The microstructure of the heat affected zone in the overheating area. Primary coarse-grained microstructure of prior austenite with grain boundaries outlined and inside ferrite plates - Widmanstätten structure. Light microscopy. Etching: Nital $4 \%$

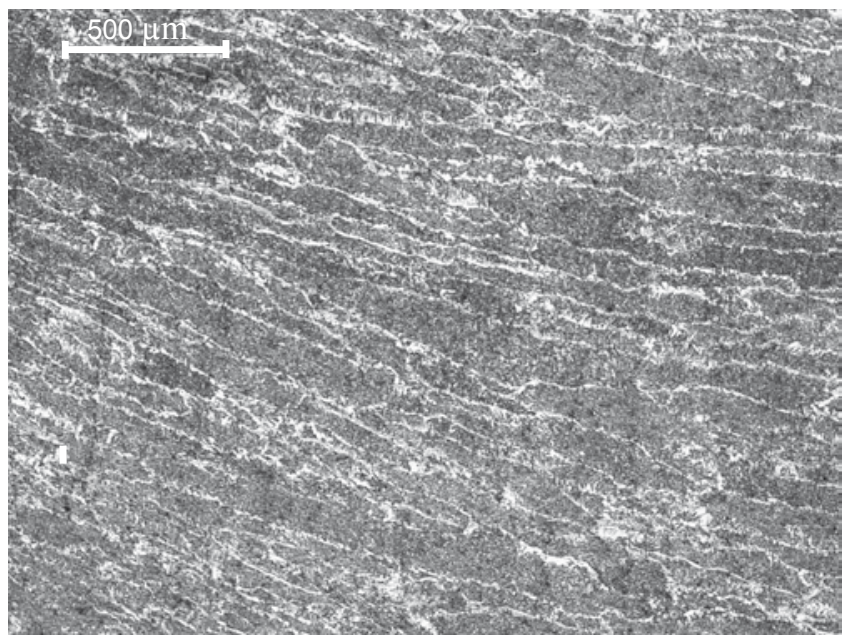

Rys. 12. Mikrostruktura w spoinie - ścieg 3. Widoczna struktura grubokrystaliczna $z$ ułożonymi krystalitami w kierunku prostopadłym do linii wtopienia przy materiale rodzimym i ściegu 1. Mikroskopia świetlna. Trawienie: Nital $4 \%$

Fig. 12. The microstructure of the weld -3 rd bead. Coarsely crystalline structure of the crystallites arranged perpendicularly to the fusion line near to base metal and 1st bead. Light microscopy. Etching: Nital $4 \%$

Tablica V. Wyniki pomiarów twardości HV10 złącza teowego ze spoiną czołową

Table V. Hardness HV10 distribution in tee-joint with butt-weld

\begin{tabular}{|c|c|c|c|c|c|}
\hline \multicolumn{2}{|c|}{ Materiał rodzimy } & \multicolumn{2}{|c|}{ Strefa wpływu ciepła } & \multicolumn{2}{|c|}{ Spoina } \\
\hline Numer pomiaru & Wartość HV10 & Numer pomiaru & Wartość HV10 & Numer pomiaru & Wartość HV10 \\
\hline 1 & 166 & 13 & 187 & 10 & 219 \\
\hline 2 & 160 & 14 & 220 & 11 & 208 \\
\hline 3 & 163 & 15 & 203 & 12 & 206 \\
\hline 4 & 196 & 16 & 195 & & \\
\hline $\begin{array}{l}4 \\
5\end{array}$ & 190 & 17 & 193 & & \\
\hline 6 & 178 & 18 & 192 & & \\
\hline 7 & 183 & 19 & 194 & & \\
\hline 8 & 180 & 20 & 185 & & \\
\hline 9 & 187 & 21 & 188 & & \\
\hline
\end{tabular}




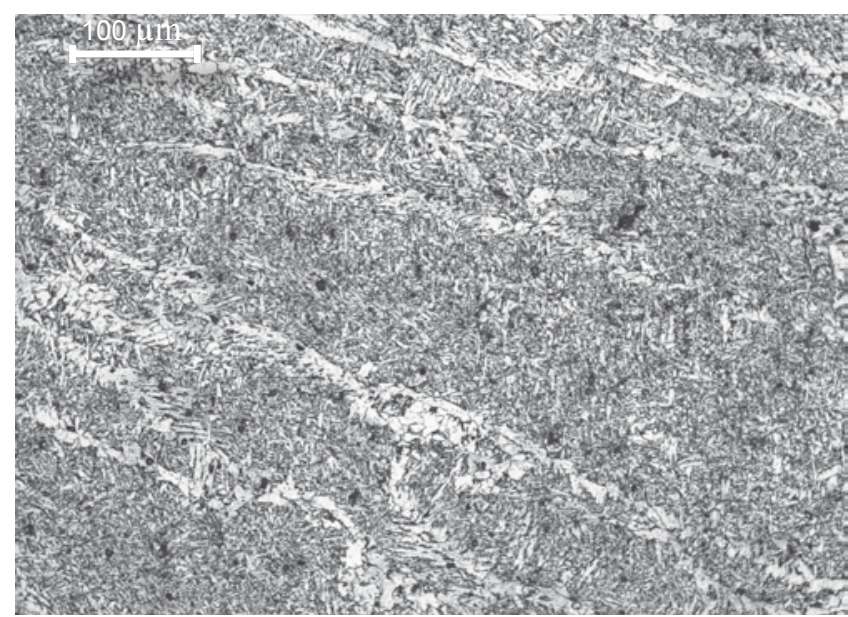

Rys. 13. Mikrostruktura w spoinie - ścieg 1 . Widoczna struktura grubokrystaliczna $z$ ułożonymi krystalitami w kierunku prostopadłym do linii wtopienia przy materiale rodzimym składającymi się z podziarn ferrytu płytkowego - struktura Widmanstättena. Mikroskopia świetlna. Trawienie: Nital $4 \%$

Fig. 13. The microstructure of the weld -1 st bead. Coarsely crystalline structure of the crystallites arranged perpendicularly to the fusion line with ferrite plates - Widmanstätten structure. Light microscopy. Etching: Nital $4 \%$

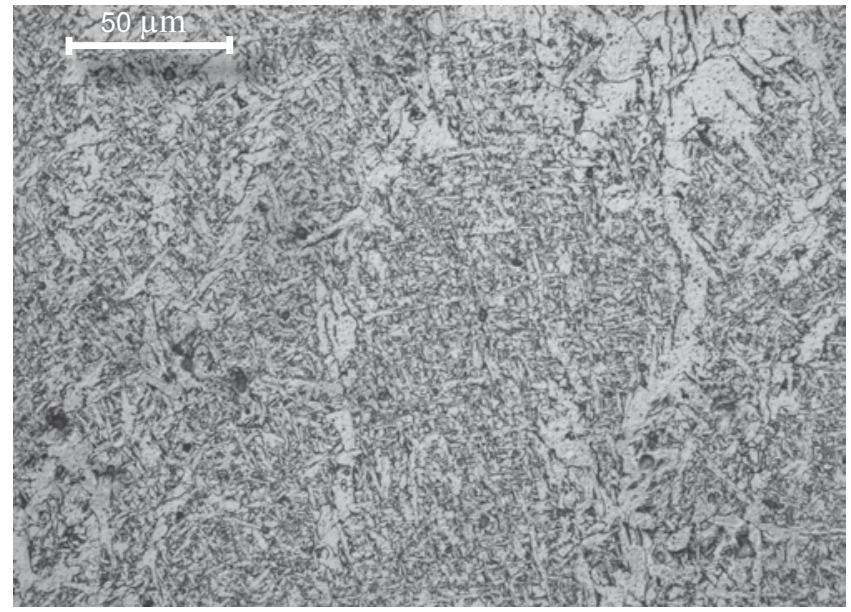

Rys. 14. Mikrostruktura w spoinie - ścieg 2. Widoczna struktura grubokrystaliczna z ułożonymi krystalitami w kierunku prostopadłym do linii wtopienia przy materiale rodzimym składającymi się z podziarn ferrytu płytkowego - struktura Widmanstättena. Mikroskopia świetlna. Trawienie: Nital $4 \%$

Fig. 14. The microstructure of the weld -2 nd bead. Coarsely crystalline structure of the crystallites arranged perpendicularly to the fusion line with ferrite plates - Widmanstätten structure. Light microscopy. Etching: Nital $4 \%$

\section{Twardość}

Pomiary twardości metodą Vickersa przy obciążeniu wgłębnika 98,1 N wykonano w charakterystycznych obszarach złącza, tzn. materiale rodzimym, strefie wpływu ciepła i spoinie. Dla każdego obszaru wykonywano po 3 pomiary. Wyniki pomiarów zestawiono $w$ tablicy $\mathrm{V}$ i na rysunku 15.

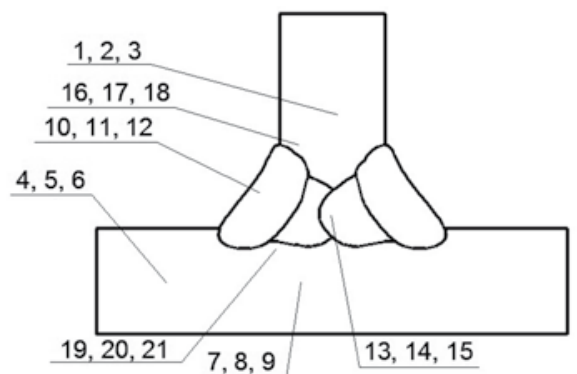

Rys. 15. Lokalizacja miejsc pomiarów twardości w złączu Fig. 15. Placement of hardness measurements in the joint

\section{Analiza wyników}

Zaprojektowane złącze teowe ze spoiną czołową możliwe jest do wykonania na zrobotyzowanym stanowisku spawalniczym przy wykorzystaniu spawania elektrodą topliwą w osłonie gazów aktywnych. Zaproponowane pozycje spawania możliwe sa do wykonania przy zastosowaniu 6-osiowego robota spawalniczego. Istotne przy doborze parametrów procesu spawania jest zwrócenie szczególnej uwagi na ilość wprowadzanego ciepła szczególnie przy ściegu 1 i 2 ze względu na naprężenia i odkształcenia powstające $w$ złączu mogące doprowadzić do powstawania pęknięć. Nie zaobserwowano pęknięć lamelarnych, które mogą występować przy tego typu złączach.

Ocena mikrostruktury złącza wykazała występowanie charakterystycznych dla stali konstrukcyjnej S355J2G3 mikrostruktur w poszczególnych obszarach złącza. Ocena twardości dla tych złączy wskazała nieznaczny wzrost twardości w SWC (o ok. 5 HV10) oraz w spoinie - o ok. 15 HV10, co jest wartością akceptowalną.

\section{Wnioski}

Przeprowadzona analiza konstrukcji złącza oraz wykonane badania pozwoliły na sformułowanie następujących wniosków:

- zaprojektowane złącze można wykonać na zrobotyzowanym stanowisku spawalniczym,

- zaproponowana konstrukcja złącza zapewnia jego poprawne wykonanie przy zachowaniu odpowiedniej ilości wprowadzanego ciepła do złącza,
- w spoinie i SWC występuje mikrostruktura charakterystyczna dla niestopowych stali konstrukcyjnych,

- w SWC i spoinie odnotowano wzrost twardości wskazujący na lepsze właściwości mechaniczne tych obszarów w porównaniu z materiałem rodzimym. 


\section{Literatura}

[1] Pfeifer T.: Rozwój rynku robotów przemysłowych w Polsce i na świecie, Przegląd Spawalnictwa 8/2011, s. 9-13.

[2] Siennicki A.: Perspektywy rozwoju robotyzacji spawania łukowego w osłonie gazowej Przegląd Spawalnictwa 8/2011, s. 3-8.

[3] Turek B.: Od 2 kilogramów do 20 ton - zrobotyzowane aplikacje spawalnicze do spawania podzespołów; Przegląd Spawalnictwa 8/2011, s. 14-18.

[4] Paul Ch., Höfner L.: Sensory w robotyzacji spawania; Przegląd Spawalnictwa 8/2011, s. 28-31.

[5] Borgosz W.: Robotyzacja spawania w produkcji wagonów towarowych robotami firmy Cloos; Przegląd Spawalnictwa 8/2011, s. 23-27.

\section{Normy}

- PN-EN 10025-2:2007 Wyroby walcowane na gorąco ze stali konstrukcyjnych - Część 2: Warunki techniczne dostawy stali konstrukcyjnych niestopowych.

- PN-EN 10027-1:2007 Systemy oznaczania stali - Część 1: Znaki stali.

- PN-EN 10027-2:1994 Systemy oznaczania stali - System cyfrowy.

- PN-EN ISO 14175:2009 Materiały dodatkowe do spawania - Gazy i mieszaniny gazów do spawania i procesów pokrewnych.

Badania przeprowadzono w ramach pracy statutowej 11.11.110.156

\section{Wydarzenia}

\section{Kemppi i zespół Williamsa odnowili umowę sponsorską}

Williams F1 Team i Kemppi ogłosili odnowienie kontraktu sponsorskiego 20 lutego 2013 w Grove w Wielkiej Brytanii.

Jest nam miło ogłosić, że Williams F1 Team podpisał kontrakt sponsorski $z$ wiodącym producentem urządzeń spawalniczych firmą Kemppi.

Kemppi to rodzinna firma założona w 1949 roku przez Martti Kemppi. Przez ponad 60 lat działalności, firma wprowadziła na rynek wiele innowacyjnych rozwiązań dla sektora stoczniowego, transportowego i zakładów zajmujących się konstrukcjami stalowymi. Firma $z$ siedzibą $w$ Lahti posiada filie w 15 krajach a regularnie swoje produkty sprzedaje do ponad 70 krajach.

Współpracę $\mathrm{z}$ Williamsem Kemppi rozpoczęło w kwietniu 2012 roku. Na mocy nowej umowy logo Kemppi będzie umieszczone na przednim spojlerze bolidu Williamsa Ranault FW35 oraz na rękawach kombinezonów kierowców. Kemppi i Williams będa kontynuować również współpracę techniczną.

Podczas rozmowy, dyrektor zarządzający Kemppi Anssi Rantasalo powiedział: „Valtteriego wspieramy od kilku lat $\mathrm{i}$ to wspaniałe, że $w$ tym sezonie ma szansę pokazać na arenie międzynarodowej na co go stać. Wspieranie jednego $z$ najlepszych zespołów $F 1$ to również ogromny zaszczyt dla Kemppi i mamy nadzieję na jeszcze więcej sukcesów Williamsa w tym roku. Nasza umowa obejmuje również współpracę technologiczną

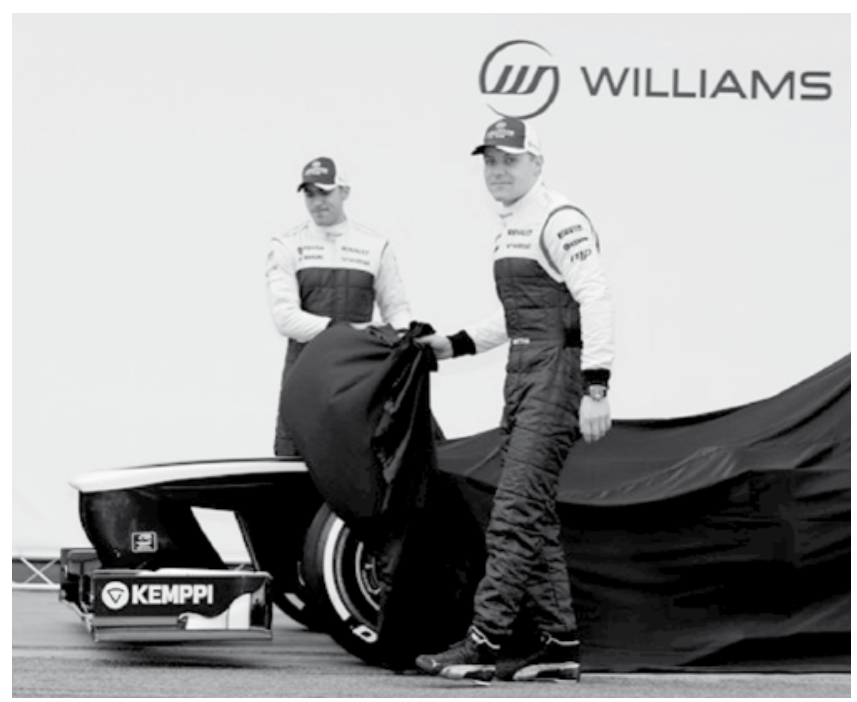

Valtteri Bottas i Pastor Maldonado odsłaniają nowy bolid FW35 w Katalonii, Hiszpania. Źródło: Williams F1 Team, 19.02.2013.

dzięki czemu udowadniamy, że nasze urządzenia spawalnicze spełniają wysokie wymagania Formuły 1 ".

Sir Frank Williams, szef zespołu Williams F1 Team dodaje: „Jesteśmy zachwyceni, że Kemppi ze swoim silnym zaangażowaniem w wyścigi samochodowe jeszcze bardziej zaangażowało się we wspieranie Williams F1 Team i liczymy na wzmacnianie naszej już silnej współpracy podczas nadchodzącego sezonu". 